\title{
Effect of Dietary Fiber and Genetic Strain on the Performance and Energy Balance of Broiler Chickens
}

-Author(s)

Krás RV 1

Kessler AM 1

Ribeiro AML

Henn JDi ${ }^{1}$

Santos II dos ${ }^{1}$

Halfen DP 1

Bockor L ${ }^{1}$

Departamento de Zootecnia, Universidade Federal do Rio Grande do Sul - UFRGS. Porto Alegre, RS

\section{Mail Adress}

Corresponding author e-mail address Rodrigo Vieira Krás

Av. Bento Gonçalves, 7712

91.540-000. Porto Alegre, RS, Brasil

E-mail: rodrigokras@yahoo.com.br

\section{"Keywords}

Cobb, Label Rouge, pair-fed, wheat bran.
Submitted: June/2011

Approved: October/2012

\section{ABSTRACT}

The experiment was conducted to evaluate the effect of dietary fiber on the performance and energy balance of broiler chickens of a fast-growing strain (Cobb500) and a slow-growing strain (Label Rokens during the period of 1 one to 42 days of used In total, 360 male broilers (240 fast-grorain and 120 slow-grtrain)were, housed in collective cages. A completely randomized experimental dewith in a $3 \times 2$ factorial arrangement was applied, consisting of three groups of birds (slow-growing - SG; fast-growing fed ad libitum - FGAL; and fast-growing pair-fed with SG broilers - FGPF) and two iso-protein dis (a $3100 \mathrm{kcal} \mathrm{ME} / \mathrm{kg}$ low-fiber diet and a $2800 \mathrm{kcal} \mathrm{ME} / \mathrm{kg}$ high-fiber diet- Hwith containing $14 \%$ wheat bran and $4 \%$ oat hulls). Dietary fiber level did not affect feed intake (FI); however, it resulted in lower weight gain (WG) and worse feed conversion ratio (FCR) $(p \leq 0.001)$ in birds fed the HFD diet due to its lower energy content. The FGPF group presented higher WG than SG and better FCR ( $p \leq 0.001)$, indicating that fast-growing birds present better performance than SG broilers, even under restricted feed intake. The SG group retained more energy relative to body weight ( $p \leq 0.001)$, which is associated to higher body fat retention in this strain $(p \leq 0.001)$. The slow-growing strain did not present better use of high-fiber diet than fast-growing strain as expected.

\section{INTRODUCTION}

The inclusion of alternative feed ingredients in poultry feeds as a consequence of the increasing use of corn and soybeans in biofuel production has increased dietary fiber (DF) levels in non-ruminants diets.

Dietary fiber is traditionally considered a diet diluent and often, an antinutritional factor (Rougière et al., 2010). However, moderate amounts of fiber may promote organ development, enzyme production, and nutrient digestibility in poultry. Some of these effects result from better gizzard function, with an increase in the gastroduodenal reflux that promotes the contact between nutrients and digestive enzymes (Mateo et al., 2012; Gonzalez- Alvarado et al., 2008; Jimenez-Moreno et al., 2009).

Commercial broiler strains have been selected for high growth rate and high feed efficiency based on the use of highly digestible diets with no metabolizable energy (ME) limitations. This selection promoted changes in digestive tract form and functions that may have impaired the utilization of low-digestibility diets (Shires et al., 1987). On the other hand, slow-growing genetic strains were not submitted to the same selection pressure; these birds are usually reared under alternative poultry production systems, and may be better adapted to lower quality diets. In Brazil, slow-growing Label Rouge strains have been 
widely used in alternative broiler production systems (Dourado et al., 2009).

The objective of this study was to compare performance and energy balance responses between a commercial fast-growing broiler strain and a slowgrowing strain fed diets containing two different fiber levels.

\section{MATERIAL AND METHODS}

In total, 360 male broilers, out of which 240 were of a fast-growing commercial strain (Cobb) and 120 of a slow-growing strain (Label Rouge), were housed in 36 battery cages with 10 birds each, in a environmentallycontrolled room with $24 \mathrm{~h}$ of light per day, from one to 42 days of age.

During the first four experimental days, all birds were fed a single pre-starter feed ad libitum. From day 5, two iso-protein diets were fed: a low-fiber diet (LFD), based on corn and soybean meal, with 3100 kcal ME/ kg; or a high-fiber diet (HFD), based on the LFD, to which $14 \%$ wheat bran and $4 \%$ oat hulls were added, containing $2800 \mathrm{kcal} \mathrm{ME} / \mathrm{kg}$, which corresponded to an increase of $7.7 \%$ in neutral detergent fiber. The LFD and the pre-starter diet were formulated to contain the nutritional levels recommended by Rostagno et al. (2011). A single experimental diet was fed during the entire period to each treatment group to allow comparing diet digestibility among different bird ages (Table 1).

The diets were fed to three different groups of 120 each: slow-growing Label Rouge birds fed ad libitum (SG), Cobb500 birds fed ad libitum (FGAL), and Cobb500 birds pair-fed with Label Rouge birds (FGPF). This last group was housed one day after the Label Rouge birds in order to receive the same amount of feed consumed by the Label group in the previous day to evaluate digestibility at the same feed intake level. Pair feeding was performed according to diet type, i.e., FGPF birds were fed once a day with the same amount of feed consumed by Label fed LFD or Label fed HFD during the previous day.

A completely randomized experimental design in a $3 \times 2$ factorial arrangement, with six treatments of six replicates each, was applied.

The following responses were evaluated: feed intake (FI), weight gain (WG), and feed conversion ratio (FCR) during the periods of 1 to 7,1 to 21,21 to 42 , and 1 to 42 days.

Energy balance and protein and fat retention were evaluated using the comparative slaughter method,
Table 1 - Composition of the experimental diets on fresh matter basis (FM).

\begin{tabular}{lccc}
\hline Diets & Pre-starter & Low fiber & High fiber \\
\hline Ingredients (\% FM) & & & \\
\hline Ground corn & 55.71 & 58.86 & 43.54 \\
\hline Soybean meal & 32 & 33.13 & 30.95 \\
\hline Wheat bran & - & - & 13.56 \\
\hline Oat hulls & - & - & 4 \\
\hline Corn gluten meal & 5 & - & - \\
\hline Vegetable oil & 2.41 & 3.76 & 3.75 \\
\hline Mono-dicalcium phosphate & 1.76 & 1.68 & 1.53 \\
\hline Limestone & 1.49 & 1.34 & 1.37 \\
\hline Salt & 0.45 & 0.46 & 0.47 \\
\hline L-Lysine.HCL & 0.48 & 0.29 & 0.31 \\
\hline DL-Methionine & 0.29 & 0.27 & 0.29 \\
\hline Sodium bicarbonate & 0.13 & - & - \\
\hline Choline chloride & 0.07 & 0.056 & 0.048 \\
\hline Mineral premix & 0.07 & 0.07 & 0.07 \\
\hline Vitamin premix ${ }^{2}$ & 0.04 & 0.035 & 0.035 \\
\hline L-Threonine & 0.05 & 0.001 & 0.03 \\
\hline Monensine (20\%) & 0.05 & 0.05 & 0.05 \\
\hline Analyzed nutritional composition & & & \\
\hline Dry matter (\%) & 8.71 & 88.38 & 88.56 \\
\hline Neutral detergent fiber (\%) & 5.21 & 5.01 & 5.3 \\
\hline Acid detergent fiber (\%) & 11.81 & 19.51 \\
\hline Crude protein (\%) & 3.63 & 7.37 \\
\hline Ashes (\%) & 19.72 & 19.95 \\
\hline Additin per kg & & & \\
\hline
\end{tabular}

'Addition per kg diet: Se 0.3 mg; 0.7 mg; Fe 40 mg; Cu 10 mg; Zn 80 mg; Mg 80 mg. ${ }^{2}$ Addition per kg diet: Vit A 8000 IU; Vit D3 2000 IU; Vit E 30 mg; Vit K 2 mg; Vit B1 2 mg; Vit B2 6 mg; Vit B6 2.5 mg; Vit B12 0.0012 mg; Biotin 0.08 mg; Pantothenic acid $15 \mathrm{mg}$; Niacin $35 \mathrm{mg}$; Folic acid $1 \mathrm{mg}$.

where one bird with average body weight per replicate was sacrificed at the beginning and at the end of the experiment. Carcass and feather samples were collected and submitted to laboratory analysis. The following parameters were calculated: total ME intake (MEI), total gross energy retention (GER), and total heat production (HP), calculated as the difference between MEI and GER, all expressed in kcal; ME intake per live weight (MEI/LW), energy retention per live weight (ER/LW), and heat production per live weight (HP/ $\mathrm{LW}$ ), expressed in $\mathrm{kcal} / \mathrm{kg}$ relative to final live weight; percentage of metabolizable energy retention (MER); crude protein retention per live weight (CPR/LW), and crude fat retention per live weight (CFR/LW), expressed in $\mathrm{g} / \mathrm{kg}$, also relative to final live weight.

Carcass dry matter, ashes, and crude protein contents were determined according to the methods of the AOAC (1995). Carcass gross energy was determined using an isoperibolic calorimeter (IKA WERKE, model (2000).

Responses were submitted to analysis of variance using the statistical software package Statgraphics 
Plus 4.1 (Manugistics, 1997). Means were compared by the test of Student-Newman-Keuls (SNK) at 5\% significance level.

\section{RESULTS AND DISCUSSION}

\section{Performance}

There was no significant interaction $(p>0.05)$ between fiber level and bird group (Table 2). However, during all evaluated periods, birds fed the HFD presented lower WG $(p \leq 0.01)$ and worse FCR ( $p \leq$ 0.001).

FI was not influenced by the diet, except for the period of 1 to 7 days, when the broilers fed the HFD had lower FI ( $p \leq 0.05)$. This result may be partially explained by the low magnitude of the evaluated values (106 $\mathrm{g}$ for LFD and $101 \mathrm{~g}$ for HFD). Also, because birds may had adapted to the pre-starter diet supplied up do day 4, the coarseness of the HFD probably caused this temporary lower feed intake.

The analysis of the total experimental period ( 1 to 42 days) confirms that FI was not affected by dietary fiber level, and that the HFD adversely affected WG and FCR ( $p \leq 0.001)$, independently of bird strain. The study of Shires et al. (1987) showed that broilers fed $6.3 \%$ higher FDA grew significantly slower. On the other hand, the observations of Rezaei \& Rajati (2010) with broilers and of Van Krimpen et al. (2009) with layers that diets with diluted energy promoted higher Fl was not confirmed in the present study. This demonstrates that birds were close to the limit of their intake capacity. Similarly, studying modern broilers strains, Raber et al. (2009) stressed the lack of an expected control of feed intake, whereas Nielse et al. (2011), working with broiler breeders, suggested that high-fiber diets may reduce hunger, thereby decreasing feed intake.

The FGAL group presented higher FI and WG ( $p$ $\leq 0.001)$ than the other groups during all evaluated periods. The feed conversion ratio of the FGAL group was better as compared to Label Rouge birds in all evaluated periods ( $p \leq 0.001)$, except between 21 and 42 days of age, when no significant differences were detected among treatments.

Fast-growing pair fed broilers presented better FCR and higher WG as compared to SG birds ( $p \leq 0.001)$ during the period of 1 to 7 days because birds were not pair-fed during the first four experimental days. Fl was no longer significantly different between these two groups during the remaining periods. From 1 to 21 days of age, WG of the SG group was not significantly different from FGPF; however, their FCR was worse ( $p$ $\leq 0.001$ ). During the period of 21 to 42 days, FGPF birds gained more weight $(p \leq 0.001)$ than SG birds, and presented better FCR than the other two groups $(p \leq 0.001)$. For the total experimental period the same trend was observed. This response may be related to a physiological adaptation to feed restriction after 21 days of age. In the present study, fast-growing Cobb broilers were superior to slow-growing Label Rouge in all performance responses, including at the same feed intake level.

Table 2 - Individual performance response of slow-growing and fast-growing broilers divided in three groups (SG, FGAL, FGPF) during the periods of 1 to 7,1 to 21,21 to 42 e 1 to 42 days of age fed diets with two fiber levels.

\begin{tabular}{|c|c|c|c|c|c|c|c|c|c|c|c|c|}
\hline \multirow[t]{2}{*}{ Age } & \multicolumn{3}{|c|}{-------- 1 to 7 d -------- } & \multicolumn{3}{|c|}{-------- 1 to 21 d -------- } & \multicolumn{3}{|c|}{-------- 21 to 42 d -------- } & \multicolumn{3}{|c|}{------- 1 to 42 d -------- } \\
\hline & $\mathrm{FI}$ & WG & FCR & $\mathrm{Fl}$ & WG & FCR & $\mathrm{FI}$ & WG & FCR & $\mathrm{FI}$ & WG & FCR \\
\hline Diet & \multicolumn{2}{|c|}{----- g/bird ----- } & $g / g$ & \multicolumn{2}{|c|}{----- g/bird ----- } & $g / g$ & \multicolumn{2}{|c|}{----- g/bird ----- } & $g / g$ & \multicolumn{2}{|c|}{----- g/bird ----- } & $g / g$ \\
\hline LFD & 105.8 & 89.0 & 1.21 & 772.7 & 557.2 & 1.40 & 2272 & 1273 & 1.78 & 3040 & 1826 & 1.67 \\
\hline HFD & 100.8 & 79.5 & 1.28 & 771.2 & 521.2 & 1.50 & 2312 & 1186 & 1.95 & 3083 & 1707 & 1.81 \\
\hline \multicolumn{13}{|l|}{ Group } \\
\hline SG & $82.8^{c}$ & $62.5^{c}$ & $1.33^{a}$ & $609.2^{b}$ & $402.7^{b}$ & $1.52^{a}$ & $1954^{b}$ & $994.0^{c}$ & $1.97^{\mathrm{a}}$ & $2563^{b}$ & $1397^{c}$ & $1.84^{a}$ \\
\hline FGAL & $125.4^{\mathrm{a}}$ & $106.7^{a}$ & $1.18^{b}$ & $1079^{a}$ & $780.5^{\mathrm{a}}$ & $1.39^{c}$ & $3050^{a}$ & $1587^{a}$ & $1.93^{\mathrm{a}}$ & $4122^{a}$ & $2361^{a}$ & $1.75^{b}$ \\
\hline FGPF & $101.6^{b}$ & $83.5^{b}$ & $1.22^{\mathrm{b}}$ & $627.7^{b}$ & $434.3^{b}$ & $1.45^{b}$ & $1872^{b}$ & $1108^{b}$ & $1.69^{b}$ & $2500^{b}$ & $1542^{b}$ & $1.62^{c}$ \\
\hline \multirow[t]{2}{*}{ SEM } & 6.77 & 7.72 & 0.06 & 32.6 & 32.1 & 0.04 & 108 & 55.5 & 0.05 & 112 & 63.7 & 0.03 \\
\hline & ------ & 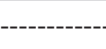 & . & 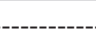 & ---- Prob & lity ----- & ---------- & --------- & -------- & --------- & & \\
\hline Diet & * & $* * *$ & $* * *$ & ns & ** & $* * *$ & ns & ** & *** & ns & $* * *$ & $* * *$ \\
\hline Group & $* * *$ & $\star \star *$ & $* * *$ & $* * *$ & $\star * \star$ & $* * *$ & $* * *$ & $\star \star *$ & $\star * \star$ & $\star \star *$ & $* * *$ & $\star \star \star$ \\
\hline Interaction & ns & ns & ns & ns & ns & ns & ns & ns & ns & ns & ns & ns \\
\hline
\end{tabular}

\footnotetext{
${ }^{a-c}$ Means followed by different letters in the same column are significantly different by the test $S N K(P \leq 0.05)$. Fl=feed intake; WG=weight gain; FCR=feed conversion ratio; LFD=low-fiber diet; HFD=high-fiber diet; SG=slow growing strain fed ad libitum; FGAL=fast growing strain fed ad libitum; FGPF=fast growing strain pair-fed with $\mathrm{SG}$; SEM=standard error of the mean; ${ }^{*}=p \leq 0.05 ;{ }^{* *}=p \leq 0.01 ;{ }^{* * *}=p \leq 0.001 ;$ ns=not significant.
} 


\section{Effect of Dietary Fiber and Genetic Strain on the Performance and Energy Balance of Broiler Chickens}

\section{Energy balance and protein and fat retention}

There was no significant interaction between fiber level and bird group for energy-balance responses (Table 3). The birds fed the LFD presented higher ME availability, producing more body fat, with higher efficiency of ingested ME utilization. Heat production relative to live weight was higher in birds fed HFD ( $p \leq$ 0.05 ), possibly due to their slower growth rate, which increases heat production associated to maintenance, and perhaps due to the higher microbial activity in the ceca as a function of the higher dietary fiber level. Total heat production, crude protein retention, and energy intake relative to live weight (MEI/LW) were not influenced by treatments. The latter result may be explained by the fact that the birds fed the HFD presented lower WG, and consequently, lower final LW.

Due to the lower heat production/live weight, higher dietary ME, and lack of FI difference, the birds fed the LFD retained more relative and total energy (ER/ LW and MER), resulting in higher carcass fat retention (CFR/LW). Conversely, Warpechowski (2005) observed compensatory ME intake in broilers fed high-fiber diets, with consequent similar heat production and energy intake between diets with different fiber levels.

The FGPF group presented lower values ( $p \leq 0.001)$ for almost all evaluated energy-balance responses than the other groups. FGAL birds presented higher MEl, GER and HP ( $p \leq 0.001)$ relative to SG birds. These responses were expected due to the high feed intake and fast growth rate of the fast-growing strain. SG birds presented higher MEI/LW ( $p \leq 0.001)$, ER/LW ( $p$ $\leq 0.001)$, HP/LW $(p \leq 0.01)$ and CFR/LW $(p \leq 0.001)$ as compared to both fast-growing groups. The highest energy intake relative to live weight (MEI/LW) of the SG group is due to their lower final weight, and possibly higher fat deposition in the carcass. The higher physical activity in the cages - which was observed during the entire experimental period in SG birds - may explain their higher heat production, which is also influenced by the higher MEI/LW. The percentage of retained energy (MER) of the SG group was not significantly different from that of the FGAL group because, despite presenting higher ER/LW, the SG group also had higher $\mathrm{MEI} / \mathrm{LW}$ and HP/LW. FGPF birds, despite their overall better $F C R$, were less efficient in retaining $M E$, as they produced leaner carcasses as a result of feed restriction.

Table 3 - Energy balance and protein and fat retention of slow-growing and fast-growing broilers divided into three groups (SG, FGAL, FGPF) and fed diets with two fiber levels during the period of 1 to 42 days of age.

\begin{tabular}{|c|c|c|c|c|c|c|c|c|c|}
\hline & MEI & GER & $\mathrm{HP}$ & $\mathrm{MEI} / \mathrm{LW}$ & ER/LW & HP/LW & MER & CPR/LW & CFR/LW \\
\hline Diet & \multicolumn{3}{|c|}{------------------ kcal ------------------ } & \multicolumn{3}{|c|}{------------------ kcal/kgPV ------------------ } & $\%$ & \multicolumn{2}{|c|}{-------- g/kgLW ------ } \\
\hline LFD & 9722 & 4111 & 5612 & 5256 & 2209 & 3040 & 42.29 & 203.1 & 113.5 \\
\hline HFD & 8998 & 3462 & 5536 & 5241 & 2015 & 3226 & 38.48 & 207.3 & 92.5 \\
\hline \multicolumn{10}{|l|}{ Group } \\
\hline SG & $7941^{b}$ & $3307^{b}$ & $4634^{b}$ & $5653^{a}$ & $2345^{a}$ & $3307^{a}$ & $41.64^{a}$ & 206.9 & $124.5^{\mathrm{a}}$ \\
\hline FGAL & $12505^{a}$ & $5149^{a}$ & $7356^{a}$ & $5245^{b}$ & $2149^{b}$ & $3084^{b}$ & $41.18^{a}$ & 207.5 & $106.6^{b}$ \\
\hline FGPF & $7634^{b}$ & $2903^{c}$ & $4732^{b}$ & $4848^{c}$ & $1841^{c}$ & $3008^{b}$ & $38.03^{b}$ & 201.2 & $77.9^{c}$ \\
\hline SEM & 364 & 176 & 345 & 130 & 103 & 150 & 2.01 & 5.66 & 10.1 \\
\hline & ------- & . & -------- & --------- P & ty ----- & ------- & ---------- & -- & \\
\hline Diet & $\star \star *$ & $* * *$ & ns & ns & $* * *$ & * & $* * *$ & ns & $* * *$ \\
\hline Group & $* * *$ & $* * *$ & $* * *$ & $* * *$ & $* * *$ & ** & * & ns & $* * *$ \\
\hline Interaction & ns & ns & ns & ns & ns & ns & ns & ns & ns \\
\hline
\end{tabular}

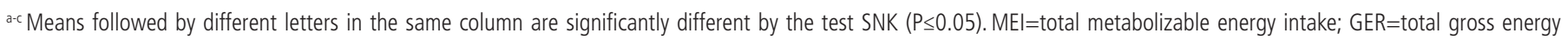

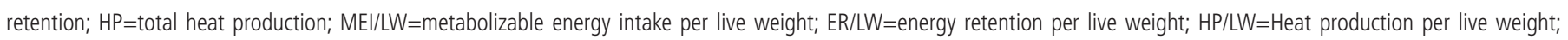
$M E R=$ metabolizable energy retention; $C P R / L W=$ crude protein retention per live weight; $C F R / L W=C r u d e$ fat retention per live weight; $L F D=l o w$-fiber diet; $H F D=h i g h$-fiber diet; $\mathrm{SG}=$ slow growing strain fed ad libitum; $\mathrm{FGAL}=$ fast growing strain fed ad libitum; $\mathrm{FGPF}=$ fast growing strain pair-fed with $\mathrm{SG}$; $\mathrm{SEM}=\mathrm{standard}$ error of the mean; * $\mathrm{p} \leq \mathrm{0.05;}{ }^{* *}=$ $p \leq 0.01 ;{ }^{* *}=p \leq 0.001 ;$ ns= not significant. 
The slow-growing Label Rouge broilers did not present better utilization of the high-fiber diet as expected; however, it must be noted that the experimental period was only of 42 days, and that the production cycle of these birds is longer than 80 days (Madeira et al., 2010). On the other hand, the inclusion of moderate amounts of dietary fiber (3\%) may improve broiler performance at early ages by reducing gizzard $\mathrm{pH}$ and improving nutrient utilization. Therefore, young broilers may require minimal amounts of fiber in the diet (Mateos et al., 2012; Jimenez-Moreno et al., 2009).

\section{CONCLUSIONS}

Broilers fed high-fiber diets presented worse performance and lower energy retention, independently of strain. Label Rouge broilers did not present better dietary fiber utilization than Cobb broilers until 42 days of age.

The hypothesis that broilers would increase their feed intake in order to compensate the lower energy intake when fed fiber-diluted diets was not confirmed, including in Label Rouge broilers.

The performance of Cobb broilers was better compared with Label Rouge birds, even when feed intake was restricted, evidencing its selection for high performance. On the other hand, Label Rouge broilers had better efficiency and consequently, higher carcass fat deposition.

\section{ACKNOWLEDGEMENTS}

The authors thank Coordenação de Aperfeiçoamento de Pessoal de nível Superior (CAPES), Ministério da Educação, Brazil, and Conselho Nacional de Desenvolvimento Científico e Tecnológico (CNPq), Ministério da Ciência e Tecnologia, Brazil for funding this study.

\section{REFERENCES}

Association of Official Analytical Chemists. Official methods of Analysis. 16th ed. Arlington: AOAC International; 1995.

Dourado LRB, Sakomura NK, Nascimento DCN, Dorigam JC, Marcato SM, Fernandes JBK. Crescimento e desempenho de linhagens de ave pescoço pelado criadas em sistema de semi-confinamento. Ciência e Agrotecnologia 2009;33(3):875-881

Gonzalez-Alvarado JM, Jiménez-Moreno E, Valencia DG, Lázaro R, Mateos GG. Effects of fiber source and heat processing of the cereal on the development and $\mathrm{pH}$ of the gastrointestinal tract of broilers fed diets based on corn or rice. Poultry Science 2008;87:1779-1795.

Jiménez-Moreno E, Gonzalez-Alvarado JM, Lazaro P, Mateos GG. Effects of type of cereal, heat processing of the cereal, and fiber inclusion in the diet on gizzard $\mathrm{pH}$ and nutrient utilization in broilers at different ages. Poultry Science 2009; 88:1925-1933.

Madeira LA, Sartori JR, Araujo PC, Pizzolante CC, Saldanha ESPB, Pezzato AC. Avaliação do desempenho e do rendimento de carcaça de quatro linhagens de frangos de corte em dois sistemas de criação. Revista Brasileira de Zootecnia 2010;39:2214-2221.

Mateos GG, Jiménez-Moreno E, Serrano MP, Lázaro P. Poultry response to high levels of dietary fiber sources varying in physical and chemical characteristics. Journal of Applied Poultry Research 2012;21-159-174.

Nielse BL, Thodberg K, Malmkvist J, Steenfeldt S. Proportion of insoluble fibre in the diet affects behavior and hunger in broiler breeders growing at similar rates. Animal 2011;5:1247-1258.

Raber MR, Ribeiro AML, Kessler AM, Arnaiz V. Suplementação de glicerol ou de lecitina em diferentes níveis de ácidos graxos livres em dietas para frangos de corte. Ciência Animal Brasileira 2009;10:745-753.

Rezaei M, Hajati $\mathrm{H}$. Effect of diet dilution at early age on performance, carcass characteristics and blood parameters of broiler chicks. Italian Journal of Animal Science 2010; 9:93-100.

Rostagno HS. Tabelas brasileiras para aves e suínos: Composição de alimentos e exigências nutricionais. 2 ed. Viçosa: UFV, Departamento de Zootecnia; 2011

Rougière N, Carré B. Comparison of gastrointestinal transit times between chickens from $\mathrm{D}+$ and $\mathrm{D}-$ genetic lines selected for divergent digestion efficiency. Animal 2010;4:1861-1872.

Shires A, Thompson JR, Turner BV, Kennedy PM, Goh YK. Rate of passage of corn-canola meal and corn-soybean meal diets through the gastrointestinal tract of broiler and white leghorn chickens. Poultry Science 1987;66:289-298.

Van Krimpen MM,Kwakkel RP, van der Peet-Schwering, CMC, den Hartog, LA, Verstegen MWA. Effects of nutrient dilution and nonstarch polysaccharide concentration in rearing and laying diets on eating behavior and feather damage of rearing and laying hens. Poultry Science 2009;88:759-773.

Warpechowski MB. Efeito do nível e fonte de fibra sobre a concentração e a utilização da energia metabolizável de dietas para frangos de corte em crescimento [tese]. Porto Alegre (RS): Universidade Federal do Rio Grande do Sul; 2005 